\title{
Weak Ankles. A Study of Common Peroneal Entrapment Neuropathy
}

\author{
J. D. SIDEY,* F.R.C.S., F.R.A.C.S.
}

\begin{abstract}
Summary: Twenty-three patients were seen with en$\checkmark$ trapment neuropathy in a two-and-a-half-year period. Symptoms consisted of pain, paresis, and paraesthesia in the distribution of the common peroneal nerve. Some degree of paresis was often present, which in five patients was severe enough to cause drop foot. In 20 patients decompression of the entrapped nerve at the neck of the fibula was quickly and completely successful. It is suggested that the ankle weakness which frequently follows sprains and other forced inversion injuries may often be at least partially due to entrapment of the common peroneal nerve.
\end{abstract}

\section{Introduction}

Peripheral entrapment neuropathy is defined as a state of altered transmission in a peripheral nerve because of mechanical irritation from related anatomical structures, from which a neuropathy may arise. This condition may vary in degree and duration, from a self-limiting condition to one progressing to permanent impairment. The best-known peripheral nerve entrapment presents as the carpal-tunnel syndrome. Nevertheless, entrapment of the ulnar nerve at the medial condyle of the humerus and of the lateral femoral cutaneous nerve under the lateral end of the inguinal ligament has been known and described for much longer, and has been reviewed by Kopell and Thompson (1963).

Entrapment neuropathy may affect the common peroneal nerve as it winds round the neck of the fibula. The entrapment may be caused by direct injury, by external or internal pressure, or by indirect causes, such as by factors which alter the axis of weight transmission. This article describes a series of 23 cases of entrapment neuropathy of the common peroneal nerve.

\section{Analysis of Patients}

The 23 patients ( 15 women and $8 \mathrm{men}$ ) in this series were aged from 15 to 60 (see Table). In three the condition was bilateral. In four its cause was direct. In 11 the cause was indirect, two being produced by closely adjacent abnormalityone a gross osteoarthritis of both knees, the other a lateral platform fracture of the tibia-and in nine the cause was more remote, following injury to foot and ankle. In eight there was no obvious cause. In one of these, an overweight girl of 15 , pain was directly related to, and much aggravated by, ballet dancing. Even when associated with direct trauma the onset of symptoms was usually insidious. A common picture following an injury, either direct or remote, was that recovery did not take place as it should-pain (frequently poorly localized) often becoming steadily worse, at first being related to activity but later occurring predominantly at rest-the ankle becoming progressively weaker. This course might take some time, often a year or more.

\section{Treatment}

Treatment was by operation, often under local anaesthesia, and consisted of carefully freeing the nerve, particularly by division of the tendinous arch of origin of the peroneus longus from the fibula. In over half the patients treated a distinct area of pressure could be seen at this point, sometimes leaving a depression or an area of hyperaemia. During operation the cutaneous branches were sought and preserved. The wound was closed by a few interrupted sutures to the superficial fascia and skin. Postoperative pain was minimal. No particular after-treatment was required, apart from a few days' rest with the leg raised and with as little weight-bearing as possible. In some cases return of muscular function was helped by graduated exercise and faradism. Rest and elevation were necessary because some increase in swelling might occur for a few days postoperatively, but this did not prevent operations being done on outpatients under local anaesthesia, provided they were able to rest at home afterwards.

\section{Results}

Five patients suffered severe paresis. These all had "drop foot"; in two of them the lesion was bilateral and in all five it was long-standing. Four out of the five showed complete recovery within six weeks and the fifth had similarly recovered, except for a persisting weakness of the extensor hallucis longus in both feet, more pronounced in the right than in the left. Weakness and sensory loss in a further patient were associated with a large scar of a war wound involving the bellies of the extensor hallucis and peroneus longus muscles ; motor recovery was incomplete because of mechanical interference by the scar. Sensory recovery was complete within a few weeks.

Of the 23 patients who have undergone operation, 21 have been relieved, 20 rapidly and completely. Eight months later the twenty-first suffered a recurrence of pain in the region of the knee which was different in nature and distribution. It appeared to be related to a mild osteoarthritic condition and disappeared after a short course of indomethacin. Three patients who required support by irons were able to discard them within three weeks of operation ; in one of these the condition was bilateral. In two patients the operation failed; in the first the condition presented as a localized peroneal entrapment, but after a brief postoperative period of improvement it was clear that she was suffering from sciatica, which has since been partially relieved by physiotherapy and support. The second initially presented with sciatica in the left leg, but after a year it appeared that her symptoms had resolved, except for pain in the common peroneal distribution, with associated sensation impairment and muscular weakness. Operation provided only partial relief. She still complained of pain on the outer side of the leg into the foot, which interfered with sleep, and progress was complicated by acute exacerbation of a peptic ulcer with an anxiety state.

In the light of subsequent experience, operation would not now be carried out on either of these patients because their clinical picture was insufficiently clear-cut. In neither did a preliminary injection of prednisolone relieve the symptoms for long enough to provide adequate proof that entrapment was present. Neither patient, however, complained of any deterioration as the result of operation.

\footnotetext{
* Consultant Orthopaedic Surgeon, Adelaide, South Australia.
} 


\section{Illustrative Case Records}

\section{Case 6}

A married woman aged 47 was first seen in hospital on 11 February 1968. She was complaining of severe poorly localized pain in the left leg. She had had an operation for prolapsed inter- vertebral disc L5-S1 five years previously, which had relieved acute left sciatica. She was left with weakness of the left foot and ankle which she had noticed for some months before operation, and which became progressively worse afterwards. She had a large semi-membranosus bursa, which was removed at operation on 12 February, but her symptoms were relieved for only 17 days, when pain returned with redoubled severity. She complained of intract-

\begin{tabular}{|c|c|c|c|c|c|c|c|c|c|c|c|c|c|c|}
\hline \multirow[b]{3}{*}{$\begin{array}{l}\text { Case } \\
\text { No. }\end{array}$} & \multirow[b]{3}{*}{$\begin{array}{l}\text { Sex } \\
\text { and } \\
\text { Age }\end{array}$} & \multicolumn{11}{|c|}{ Summary of Cases } & \multirow[b]{3}{*}{$\begin{array}{l}\text { Speed } \\
\text { and } \\
\text { Degree of } \\
\text { Recovery }\end{array}$} & \multirow[b]{3}{*}{ Comment } \\
\hline & & \multirow[b]{2}{*}{$\begin{array}{l}\text { Side } \\
\text { Cause }\end{array}$} & \multicolumn{3}{|c|}{ Motor Effects } & \multicolumn{5}{|c|}{ Sensory Effects } & \multirow[b]{2}{*}{ Ankle } & \multirow[b]{2}{*}{$\begin{array}{l}\text { Opera- } \\
\text { tion } \\
\text { Date }\end{array}$} & & \\
\hline & & & $\begin{array}{l}\text { Weak- } \\
\text { ness }\end{array}$ & $\underset{\substack{\text { Ankle } \\
\text { Instabil- } \\
\text { ity }}}{\mid}$ & $\begin{array}{l}\text { Foot } \\
\text { Drop }\end{array}$ & $\begin{array}{l}\text { Paraes- } \\
\text { thesiae }\end{array}$ & $\begin{array}{c}\text { Numb- } \\
\text { ness }\end{array}$ & $\begin{array}{c}\text { Clinical } \\
\text { Sensa- } \\
\text { tion } \\
\text { Impair- } \\
\text { ment }\end{array}$ & Pain & Cramp & & & & \\
\hline 1 & F 35 & L, none & - & - & - & + & - & - & +++ & \pm & - & $1 / 9 / 66$ & $\begin{array}{l}\text { Rapid, } \\
\text { complete }\end{array}$ & \\
\hline 2 & F 15 & $\begin{array}{l}R \text {, overweight } \\
\text { ballet dancer }\end{array}$ & - & \pm & - & - & + & \pm & +++ & - & + & $19 / 12 / 66$ & $\begin{array}{l}\text { Slow; com- } \\
\text { plete after } \\
9 \text { months } \\
\end{array}$ & \\
\hline 3 & F 57 & $R$, none & + & - & - & - & - & - & ++ & - & - & $6 / 1 / 67$ & $\begin{array}{l}\text { Transitory, } \\
\text { slight im- } \\
\text { provement }\end{array}$ & $\begin{array}{l}\text { Failure-probably } \\
\text { misdiagnosis }\end{array}$ \\
\hline 4 & F 57 & $\underset{\text { ritis both knees }}{\text { Gross osteoarth- }}\left\{\begin{array}{l}R \\
L\end{array}\right.$ & $\begin{array}{c}++ \\
++\end{array}$ & $\begin{array}{c}++ \\
++\end{array}$ & $\begin{array}{l}+ \\
\pm\end{array}$ & $\begin{array}{l}+ \\
+\end{array}$ & - & - & $\begin{array}{l}+ \\
+\end{array}$ & $\begin{array}{c}++ \\
++\end{array}$ & $\begin{array}{c}++ \\
+\end{array}$ & $\begin{array}{l}17 / 5 / 67 \\
18 / 9 / 67\end{array}$ & $\begin{array}{l}\text { Rapid, } \\
\text { complete }\end{array}$ & \\
\hline 5 & M 40 & $\begin{array}{c}R \text {, platform fracture } \\
\text { tibia, 4/8/67 } \\
\end{array}$ & - & - & - & + & + & + & - & - & - & $23 / 10 / 67$ & $\begin{array}{c}\text { Rapid, } \\
\text { complete }\end{array}$ & $\begin{array}{l}\text { Weakness of exten- } \\
\text { sor hallucis only }\end{array}$ \\
\hline 6 & F 47 & $\begin{array}{l}\text { L, laminectomy for } \\
\text { P.I.D. L5/S1, } 1963\end{array}$ & +++ & + & + & - & ++ & ++ & +++ & $\overline{t++}$ & + & $23 / 3 / 68$ & $\begin{array}{l}\text { Rapid, } \\
\text { complete }\end{array}$ & $\begin{array}{l}\text { Previous operation } \\
\text { for semi-mem- } \\
\text { branosus bursa, L } \\
\end{array}$ \\
\hline 7 & F 29 & $\begin{array}{l}\mathrm{L}, \text { long history, } \\
\text { since } 15\end{array}$ & - & - & - & + & - & - & $\underset{\text { mainly }}{+++}$ & + & - & $8 / 4 / 68$ & $\begin{array}{l}\text { Rapid (recur- } \\
\text { rence of pain } \\
\text { in same leg) }\end{array}$ & $\begin{array}{l}\text { Recurrence of pain } \\
\text { in knee } 8 \text { months } \\
\text { later, relieved by } \\
\text { indomethacin } \\
\end{array}$ \\
\hline 8 & F 30 & L, none & \pm & \pm & - & \pm & \pm & \pm & ++ & - & - & $11 / 4 / 68$ & $\begin{array}{l}\text { Rapid, } \\
\text { complete }\end{array}$ & \\
\hline 9 & F 23 & $R$, none & \pm & $\pm ?$ & - & - & + & - & ++ & ++ & - & $31 / 5 / 68$ & $\begin{array}{c}\text { Rapid, } \\
\text { complete }\end{array}$ & \\
\hline 10 & M 18 & $\begin{array}{l}R \text {, heavy blow on } \\
\text { ankle }\end{array}$ & ++ & ++ & - & - & + & + & - & - & + & $2 / 7 / 68$ & $\begin{array}{l}\text { Full in } \\
6 \text { months }\end{array}$ & \\
\hline 11 & F 48 & $\begin{array}{l}\text { Severe ankle injury. } \\
R, 1963\end{array}$ & +++ & +++ & $\begin{array}{c}+ \text { Wore } \\
\text { irons and } \\
\text { T-strap } \\
4 \text { years } \\
\end{array}$ & - & + & + & ++ & + & ++ & $27 / 7 / 68$ & $\begin{array}{l}\text { Full in } \\
6 \text { weeks }\end{array}$ & $\begin{array}{l}\text { Subtaloid osteo- } \\
\text { arthritis }\end{array}$ \\
\hline 12 & F 28 & $\begin{array}{c}\text { Fracture neck. } \\
\mathbf{R} \text {, fibula }\end{array}$ & \pm & \pm & - & - & - & - & +++ & - & - & $26 / 8 / 68$ & $\begin{array}{l}\text { Full in } \\
5 \text { weeks }\end{array}$ & \\
\hline 13 & F 20 & $\begin{array}{l}\text { R, direct (dash- } \\
\text { board injury } \\
1 / 5 / 68 \text { ) } \\
\end{array}$ & \pm & - & - & - & + & $\stackrel{ \pm}{\text { patchy }}$ & $\begin{array}{c}++ \\
\text { mainly } \\
\text { nocturnal }\end{array}$ & - & \pm & $12 / 9 / 68$ & $\begin{array}{l}\text { Full in } \\
6 \text { weeks }\end{array}$ & \\
\hline 14 & F 41 & $\begin{array}{l}\text { L, several accidents } \\
\text { at work }\end{array}$ & + & - & - & + & \pm & $\begin{array}{c}+ \\
\text { patchy }\end{array}$ & ++ & - & - & $17 / 9 / 68$ & $\begin{array}{l}\text { Slight transi- } \\
\text { tory improve- } \\
\text { ment }\end{array}$ & $\begin{array}{c}\begin{array}{c}\text { Failure. } \\
\text { neurotic, } \\
\text { ulcer }\end{array} \\
\end{array}$ \\
\hline 15 & F 35 & \begin{tabular}{|l}
$L$, indirect Sept. \\
1965
\end{tabular} & +++ & ++ & + & + & + & - & ++ & ++ & + & $\overline{12 / 10 / 68}$ & Rapid, full & $\begin{array}{c}\text { Subtaloid osteo- } \\
\text { arthritis }\end{array}$ \\
\hline 16 & M 43 & $\begin{array}{l}\text { L, direct shrapnel } \\
\text { wound Stalingrad }\end{array}$ & ++ & + & - & - & ++ & ++ & - & - & - & $23 / 10 / 68$ & $\begin{array}{l}\text { Motor incom- } \\
\text { plete. } \\
\text { Sensory } \\
\text { complete } \\
\end{array}$ & $\begin{array}{l}\text { Large scar involving } \\
\text { extensor hallucis } \\
\text { muscle and pero- } \\
\text { neus longus } \\
\end{array}$ \\
\hline 17 & M 53 & $\begin{array}{l}\mathrm{L}, \text { truck ran over } \\
\text { big toe, } 8 / 5 / 67 \\
\text { (indirect injury) } \\
\end{array}$ & ++ & ++ & - & - & + & + & ++ & - & + & $\overline{11 / 11 / 68}$ & $\begin{array}{l}\text { Almost } \\
\text { complete in } \\
2 \text { months } \\
\end{array}$ & $\begin{array}{l}\text { Now fully } \\
\text { recovered }\end{array}$ \\
\hline 18 & M 55 & $\begin{array}{c}\text { L, no obvious cause. } \\
\text { Previous explora- } \\
\text { tion sciatic nerve } \\
\end{array}$ & ++ & + & - & + & + & ++ & ++ & ++ & - & $28 / 12 / 68$ & $\begin{array}{l}\text { Full in } \\
8 \text { weeks }\end{array}$ & \\
\hline 19 & F 39 & $\begin{array}{l}\text { Direct injury on } \\
\text { dashboard in car } \\
\text { accident. } 26 / 7 / 66 . \\
\text { Bilateral }\end{array}$ & - & - & - & $\begin{array}{l}- \\
-\end{array}$ & $\begin{array}{l}- \\
-\end{array}$ & - & $\begin{array}{l}++ \\
++ \\
\end{array}$ & $\begin{array}{l}++ \\
++ \\
\end{array}$ & $-i$ & $1 / 2 / 69$ & $\begin{array}{l}\text { Full in } \\
5 \text { weeks }\end{array}$ & $\begin{array}{l}\text { Complicated by } \\
\text { attack of Graves's } \\
\text { disease }\end{array}$ \\
\hline 20 & M 60 & $\begin{array}{c}\text { None obvious. } \\
\text { Bilateral } \\
\mathbf{R} \\
\mathbf{L}\end{array}$ & $\stackrel{+}{+}$ & $\stackrel{+}{+}$ & $\stackrel{+}{+}$ & $\overline{-}$ & $\overline{-}$ & $\overline{-}$ & $\stackrel{+}{+}$ & $\stackrel{+}{+}$ & +1 & $24 / 2 / 69$ & $\begin{array}{l}\text { Full except } \\
\text { extensor } \\
\text { hallucis } \\
\text { longus }\end{array}$ & $\begin{array}{l}\text { Pension entitlement } \\
\text { metatarsalgia and } \\
\text { claw toes since } \\
1942 \text {. Iron and } \\
\text { T-strap both legs } \\
\text { discarded 10/3/69 } \\
\end{array}$ \\
\hline 21 & F 49 & L, none & - & - & - & + & + & - & ++ & + & - & $11 / 3 / 69$ & $\begin{array}{l}\text { Immediate } \\
\text { loss of pain } \\
\text { and } \\
\text { subjective } \\
\text { sensations } \\
\end{array}$ & $\begin{array}{l}\text { Full recovery by } \\
\text { June } 1969\end{array}$ \\
\hline 22 & M 41 & $\begin{array}{l}\text { Inversion/adduction } \\
\text { injury, } L \text {, ankle, } \\
22 / 3 / 63\end{array}$ & + & \pm & - & - & + & + & ++ & - & + & $2 / 11 / 68$ & \begin{tabular}{|l|} 
Gradual \\
improvement, \\
complete in \\
8 months \\
\end{tabular} & \\
\hline 23 & M 25 & $\begin{array}{l}\text { Inversion injury, } \\
\mathrm{L} \text { foot }\end{array}$ & ++ & + & - & - & - & - & + & - & + & $11 / 3 / 69$ & $\begin{array}{l}\text { Complete in } \\
3 \text { weeks }\end{array}$ & \\
\hline
\end{tabular}


able nocturnal cramp, which woke her several times a night. She had suffered from this for four years, but it had become much worse. Examination showed paresis affecting only the muscles supplied by the common peroneal nerve and an area of hypoaesthesia over the lateral aspect of the leg and dorsum of the foot.

Common peroneal decompression was done on 23 March. All her symptoms were relieved immediately; by 11 April she showed virtually complete recovery of strength in foot and ankle. Four months later she was walking normally, making no complaints. She had had neither cramp nor pain and could run, which she had been unable to do for about seven years. Although she was appreciative of the recovery in strength to normal, she was most grateful for the relief of her pain.

\section{Case 11}

A married woman aged 48 was originally referred for pain in the left arm caused by acute carpal-tunnel syndrome. During her convalescence she complained of weakness and pain in the right leg. Five years previously she had sustained a severe adduction/ inversion sprain of the right ankle. She had jumped off a chair and landed with her right foot on a large plug so that her ankle "went over" and she fell heavily. After initial recovery, weakness and pain in her ankle increased over the next three months. Her doctor had the ankle radiographed, no abnormality being found. For another six months she continued at work, but pain and weakness in the right leg and ankle steadily worsened. Finally, another $x$-ray examination was carried out by an orthopaedic surgeon, who found that in the six months since the previous $x$-ray examination an appreciable degree of subtaloid osteoarthritis had developed. The patient was offered and accepted a subtaloid fusion, but as she refused general anaesthesia operation was not carried out.

For the next four years she wore an inside and outside iron and T-strap, but the condition gradually progressed to a "drop foot" accompanied by considerable pain and nocturnal cramp, with little alteration of sensation. Clinical examination localized the lesion to the common peroneal nerve, which was decompressed on 27 July 1968. Pain and cramp disappeared in 48 hours. In a few days her walking had improved and within three weeks full muscular strength had returned; she was walking normally; she could run up and down steps, which she had been unable to do since the original accident. Within six weeks of operation she had returned to her original part-time occupation of swimming instructress, which she had been unable to do since the original accident. She has remained well.

\section{Case 19}

A married woman aged 39 was involved in a head-on car collision on 26 July 1966, when she was thrown forwards and sustained a heavy blow on the head from the windscreen, while both flexed knees were brought forcibly into contact with the dashboard. On 6 February 1967 she complained of severe poorly localized continuous pain in the region of the right knee. Careful repeated examination and investigation showed no evidence of internal derangement of the knee joint. She was not seen for 10 months while her thyrotoxicosis was being successfully treated, but she returned in December 1967, complaining of pain in both knees, the right being worse than the left.

Further repeated examinations showed no intra-articular cause of her pain. Though there was no evidence of weakness of any of the leg muscles, nor evidence of sensation alteration, there was pronounced tenderness over both peroneal nerves at the neck of the fibula. Ultimately injection of betamethasone on the right side resulted in complete cessation of pain in that knee and leg for six weeks. Bilateral peroneal nerve decompression was carried out on 1 February 1969 with rapid relief of pain and nocturnal cramp, which had become increasingly severe since the accident. Four months afterwards she remained symptom-free.

\section{Case 22}

On 22 March 1963 a man aged 41 got his left foot jammed between a tractor linkage and its axle, twisting his ankle in forcible adduction/inversion. $X$-ray examination at the time showed no fracture, but four months later he complained of persisting pain, swelling, and weakness in the ankle unaffected by support and by vigorous active physiotherapy. The ankle presented the appearance of chronic "sprain" affecting the lateral ligament of the ankle joint. Active treatment along the same lines was continued with no improvement ; in March 1965 he first complained of a feeling of numbness on the dorsum of the foot, and a patch of hypoaesthesia was found. For the next two years he continued to have trouble but could play tennis if the ankle was tightly bandaged to prevent it "going over." By October 1968 he was no longer able to play tennis, ankle weakness had increased, and a slight evertor and dorsiflexor muscular weakness was found, with greatly increased tenderness over the common peroneal nerre at the fibular neck.

Operation was done on 2 November; there was clear evidence of entrapment. By 5 February 1969 muscular strength had recovered fully. He required no support and was able to play tennis normally. Though he still complained of numbness over the dorsum of the foot, no alteration of sensation could be found. By June 1969 he was symptom-free.

\section{Discussion}

The results of treatment by a simple and harmless operation are on the whole very satisfactory, and as with experience diagnosis improves they should become more so. As in most other cases of peripheral entrapment neuropathy, relief of pain is a very important result, but of equal importance is the relief of paresis, sometimes of long duration. However long the paresis has been present, it seems to resolve at about the same rate. Examination of large numbers of patients with knee injuries leaves a small percentage in whom no definite diagnosis presents ; this seems to be particularly so when the flexed knees are injured by forcible impact against a dashboard, a very common accident nowadays. In such cases the possibility should be considered that the pain may be caused by common peroneal entrapment after direct injury. Two patients in this series sustained such an injury; in one, repeated examination was carried out for two and a half years before a definite diagnosis could be made, but once this was done treatment brought complete relief and to date has removed her disability.

\section{Aetiology}

Part of the vulnerability of the common peroneal nerve at the neck of the fibula is its situation, as It lies deep only to skin and fascia and directly on bone. Nevertheless, probably the greater part is due to the changes in tension which occur under the sharp crescentic arch of the tendinous origin of peroneus longus (Kopell and Thompson, 1960, 1963).

The nerve may be affected by direct trauma from a blow or maintained external pressure, by fracture of the fibular neck, or from deep pressure (as from a tumour). Indirectly, it is affected by factors altering weight transmission, such as gross osteoarthritis of the knee joint or platform fracture of the tibia, but most often these indirect forces are more distant, frequently resulting from adduction/inversion injury to the foot and ankle. Such injuries may be severe, causing either fracture or dislocation, or more commonly a "sprained ankle." Occasionally, when the ankle swelling and local soreness have subsided, trouble may persist as a disabling state of chronic or recurrent sprain; an ankle which repeatedly "turns over" causing swelling in the region of the external malleolus and distal to it, with considerable pain. Attention is focused on this ankle weakness, with its supposed ligamentous laxity. In only a few cases is such laxity demonstrable; where it cannot be shown treatment tends to be unsuccessful. Such a condition may progress insidiously yet steadily to a complete "drop foot."

In a short paper on lateral popliteal nerve compression (Marwah, 1964) it was postulated that the main focus of com- 
pression was in a fibro-osseous canal formed by the thick fascia which overlies the peroneal nerve at the fibular neck. In the first patient, when only this fascia was divided, the condition recurred. It was not until a complete neurolysis was done, dividing the tendinous arch of origin of peroneus longus, that rapid and permanent relief was obtained.

\section{Clinical Picture}

The results of entrapment may be both motor and sensory, the picture varying from virtual complete paralysis of all the muscles supplied (resulting in "drop foot") to no muscular abnormality whatever, though some degree of paresis is usually found. The commonest symptom is pain, which may be severe and disabling, and which is usually present. Less commonly paraesthesiae and numbness occur; these are less often nocturnal than in certain other peripheral entrapment neuropathies -for example, carpal-tunnel syndrome. Nocturnal cramp is common. Less frequently there is complaint of coldness below the knee and in the foot. Well-defined sensory impairment is less common than paresis, but sometimes there is partial or, rarely, complete anaesthesia over the sensory distribution of the nerve. Though the normal nerve at the neck of the fibula is not sensitive to palpation or to gentle percussion, commonly there is pronounced local tenderness over the nerve at the fibular neck in entrapment. Reflexes are normal, and there is seldom muscular wasting. The major symptoms may be summarized as follows: pain, paresis, paraesthesiae and numbness, and nocturnal cramp.

\section{Diagnosis}

Severe nerve injuries, neurotmesis, and axonotmesis, involving complete interruption of all nerve transmission with consequent total paralysis and sensation loss, are distinguishable from entrapment neuropathy, where complete interruption never occurs. The lesion of entrapment and that of neurapraxia have, however, some points in common. Neurapraxia is a temporary interference with nerve transmission showing initially full effects of the exciting cause, and improving steadily to complete return of function. All three of these nerve injuries, but not peripheral entrapment neuropathies, may cause loss of tendon reflexes. The effects of entrapment are variable, intermittent, and capricious, either predominantly motor or sensory, which effects are seldom concomitantly severe. Though sometimes self-limiting, entrapment effects usually continue to be felt until their cause is removed. Probably entrapment effects are mainly due to pressure avascularity and hence anoxia in a localized segment of nerve (Kremer et al., 1953). If recovery after decompression is incomplete, which does occur, the implication is that because of long-standing or unusually heavy pressure permanent change has occurred in the nerve fibre or its sheath (Semple and Cargill, 1969).

Diagnosis depends on the taking of a very careful and detailed history followed by thorough physical examination, which must include a general examination. Muscle tests must be carried out clinically and by electromyography; by this means peripheral neuritis can be eliminatd, particularly as in established peri- pheral neuritis there is alteration of tendon reflexes. Similarly, careful history-taking and clinical examination should eliminate conditions such as vascular insufficiency (which may closely simulate the effects of peroneal entrapment) and of disease of the central nervous system. The history is often characteristic and the clinical signs are few, so that, as in entrapment neuropathy elsewhere, initial diagnosis must be made on history alone.

A reliable clinical test which can be carried out quickly and easily is the injection of one of the prednisolone derivatives at the point of entrapment in the region of the tendinous arch of the peroneus longus. Because of the risk of a complete drop foot of some hours' duration, it is important not to inject local anaesthetic into this region. Not only will this prednisolone test relieve pain, sometimes for a few weeks, but in at least one patient there was an appreciable increase in muscular strength within a few minutes of the injection.

If only those muscles supplied by the common peroneal nerve are affected, and if the sensory alterations are within the supply of the nerve, probably the causative factor will be somewhere along the short course of the nerve to its termination by division into its two major branches.

In an appreciable number of patients there seems to be no definite reason for nerve entrapment to arise. In these patients diagnosis is more difficult, as it is in another group-namely, those who have sustained a distant indirect injury, perhaps initially not even considered a serious one. Typically this is regarded as a "sprain" of the ankle; it does not get better and continues to the common picture of persistent weakness and swelling, with a tendency for the ankle to "go over."

This series suggests that, though there may be a component of ligamentous injury to the ankle, the possibility of muscular insufficiency from peroneal nerve involvement should be considered. This nerve entrapment may be the cause of a great deal of persistent ankle disability. The relief of chronic and at times crippling disability following relatively trivial injury can be striking. Experience with peripheral entrapment neuropathy elsewhere-in particular, the carpal-tunnel syndromehas been that relief of compression is followed by quick cessation of symptoms and a rapid return to full function, and this has proved to be so in the present series of cases. Semple and Cargill (1969), however, observe that after operation full recovery may not occur in the more long-standing cases of carpal-tunnel syndrome. Hence there is little point in delaying decompression once a diagnosis has been made at other sites of peripheral nerve entrapment.

Please address requests for reprints to Mr. J. D. Sidey, 142 Ward Street, North Adelaide, 5006, South Australia.

\section{REFERENCES}

Kopell, H. P., and Thompson, W. A. L. (1960). New England fournal of Medicine, 262, 56.

Kopell, H. P., and Thompson, W. A. L. (1963). Peripheral Entrapment Neuropathies. Baltimore, Williams and Wilkins.

Kremer, M., Gilliatt, R. W., Golding, J. S. R., and Wilson, T. G. (1953). Lancet, 2, 590.

Marwah, V. (1964). Lancet, 2, 1367.

Semple, J. i.., and Cargill, A. O. (1969). Lancet, 1, 918. 